\title{
Professional and Ethical Conduct in the Public Sector
}

Thozamile Richard MLE

Abstract

$\mathrm{O}$ ne of the basic values and principles governing public administration enshrined in the Constitution of the Republic of South Africa, 1996 (Chapter 10) is that "a high standard of professional ethics must be promoted and maintained. Ethics is a process by which we clarify right and wrong and act on what we take to be right, that is, a set or system of moral principles that are generally accepted. Ethics simply means what is right and wrong, what is acceptable or unacceptable and is intertwined with the value system of people. Ethics can also be seen as being relative, not absolute, as ethical behaviour is in the eyes of the beholder. Be that as it may, however, ethical conduct and behaviour normally refer to conforming with generally accepted social norms.

Relative to ethics is professionalism, which entails a high standard of work and adherence to certain standards and principles pertaining to specific work to be done. Professionalism embodies skills,

competence, efficiency and effectiveness. Public institutions exist for the public good and employ public servants to render services to ensure a better life for all. The public sector is characterised by unprofessional and unethical conduct. The article unearths these and suggests strategies/mechanisms to address this 'ill'. Can an unethical, unprofessional public servant be trusted to deliver services? Can, for example, a debt-trapped public servant who survives on borrowing money from micro-lenders, who cannot manage personal finances, be trusted to efficiently manage public funds and thus enhance service delivery? Can an incompetent, corrupt, disloyal, unaccountable, shoddy public servant who flouts the principles of Batho Pele and the code of conduct be entrusted with the responsibilities of ensuring a better life for all? The answers to these questions constitute the core of this article.

Keywords: Public Sector, Public Servant, Ethics, Professional Conduct, South Africa. 


\section{INTRODUCTION}

In terms of Chapter 2 (Bill of Rights) of the Constitution of the RSA of 1996, all citizens of the country have a right to have their basic needs that promote their welfare met. Every government, therefore, must endeavour to promote the general welfare of its citizens, (De Bruijn \& Dicke, 2006:79). When a legislature identifies a need for a service to be rendered to a community, the legislature or parliament will create a department to render such a service. Only the legislature has a right to create, abolish, merge or amalgamate departments.

One of the processes of public administration is human resource, thus for services to be rendered by a department there is a need for personnel to be employed and attached to specific posts within the organisational structure of the particular department. This process is accompanied by; inter alia, allocation of functions, delegation of authority, creation of communication channels and behavioural relationships. Such personnel employed, sometimes referred to as functionaries, are charged with the task of ensuring that a department's or a municipality's goals are achieved through efficient, effective performance of duties, the requisite for success being ethical conduct and professionalism on the part of the functionaries (Shafritz \& Russel, 2005:15). Put differently, there is little or no hope of success in the delivery of services if the public servants are not professional and their conduct not ethical.

According to Andrews (1988:35), ethics refers to the standard which guides the behaviour and actions of personnel in public institutions and which may be referred to as moral laws. The modernisation of methods and procedures as well as technological progress is useless if the personnel who must apply the methods and procedures do not aspire to high moral standards. The question is whether the South African public service is governed or characterised by a high standard of professional ethics or not. What is the reality on the ground and what effect does it have on public service delivery? These questions need to be answered in relation to the sentiments expressed by President Zuma that government must work faster, harder and smarter (SONA, 2010:4).

According to Gildenhuys (1991:41), poor, dishonest management of public affairs and corruption (immoral acts) are among the most important manifestations of unethical conduct. Maladministration and corruption in the public sector are usually widely broadcast and exaggerated, largely because the public sector is spending taxpayers' money. For practitioners in the public sector, especially for public managers, it is important that there be guidelines according to which they must cooperate and administer and direct the public service, and 
place subordinates on the right track precisely to prevent corruption and eliminate maladministration.

Bureaucrats are often suspected of lining their own pockets at the cost of the citizens. Opportunities for public servants to be involved in unethical conduct arise from the power they exercise in both the development and administration of public policy.

\section{PUBLIC SERVICE COMMISSION FINDINGS}

The Public Service Commission is an organ of the state established in terms of the constitution to, inter alia, promote the values and principles governing public administration in the Republic and to promote measures that ensure effective and efficient performance within the public service. In its report on the State of the Public Service (2008), the Public Service Commission highlighted some areas of concern about the professional and ethical conduct of public servants. There are activities that constitute unethical and unprofessional conduct in the public service, and some will now be explained.

\section{Activities constituting unethical conduct}

The South African Public Service is characterised by activities which constitute unethical conduct and the following may be mentioned as examples with a sample being explained:

- Bribery, graft, patronage, nepotism and influence peddling

- Conflict of interest, including activities such as making financial transactions for personal advantage, and accepting outside employment during tenure in government without declaring this

- Misuse of inside knowledge, for example, through acceptance of a business appointment after retirement or resignation

- Favouring relatives and friends in awarding contracts or arranging loans and subsidies

- Accepting improper gifts and entertainment

- Protecting incompetence

- Regulating trade practices or lowering standards in such a manner as to give advantage to oneself or relatives

- The use and abuse of official and confidential information for private purposes. 


\section{Diversion of public resources}

Public assets or the services of public servants are sometimes used for private purposes. This can be seen as rent-seeking behaviour where the focus is on accessing public resources and services. Larmour (1990:64) makes the point that people are self-interested and opportunistic maximisers. Public equipment, office supplies and other stock may be used for the improvement and maintenance of a public official's private property. Public servants are sometimes used as workers in political campaigns while on government time - an illegal advantage of incumbency. This is straightforward stealing.

\section{Delivering low quality materials}

The delivery of low-quality materials, lower than specified in the relevant contract, is another example of unethical and unprofessional conduct. Higher contract prices for higher quality materials are paid for lower quality materials worth much less. Quality is related to the principle of value for money, which entails that services need to be provided efficiently, effectively and economically.

\section{Bid rigging}

Procurement fix involves the rigging of bids or supply of contracts. Potential suppliers agree beforehand among themselves on the bid winner and the winning price - other companies would submit non-competitive tenders at much higher prices. This conspiracy increases the profits of the company as well as the cost to the government. Public officials could be involved and could receive bribes, what is usually referred to as kickbacks, to enlist their cooperation. So rampant is bid rigging in the public service and in municipalities that those who illegally benefit from this practice are referred to as 'tenderpreneurs' or 'tender-licking good'.

This is unethical conduct where business is not conducted with integrity, is unfair and unreasonable. It can also be seen as financial mismanagement, which frustrates the achievement of a departmental goal. Bayat and Meyer (1994) state that people are usually shocked when corruption in a state department is uncovered, or when a politician who occupies a position of public trust is implicated in a scandal. These activities are manifestations of the frailties of men and will be encountered wherever human beings are found.

Corruption taints the image of the public service, and it is therefore a source of concern to most citizens. It deprives the citizens of services due to them. Bayat 
and Meyer mention possible causes of corruption as greed, presence of an ethos of corruption, unchallenged governments, nepotism, patronage, flouting codes of conduct, differing ethical values and norms, emulating corrupt leaders, unwavering trust in political office-bearers, lack of adequate checks and balances and preoccupation with official secrecy.

\section{Public servants trapped in debt}

Public servants are not simply employees of the state, but have a constitutional role to play. These employees must be responsive to the government of the day and play a vital role in ensuring a better life for all by enhancing service delivery through the efficient, economic and effective use of resources. Public servants, however, have lives beyond the office and sometimes these lives have an impact on their work performance. This begs for employee wellness from the perspective that employees are most productive when they are well physically, mentally and financially. The question is whether or not a public servant who is unable to manage his/her personal finances and is heavily trapped in financial debt is able to efficiently and effectively manage public resources and be productive enough to meet the expectations of the public and the principles of Batho Pele, which seek to enhance service delivery without unethical behaviour. This challenge is derived from the Public Service Commission Report (2008:32), which states that public servants are trapped in financial debt and this creates doubt as to their ability to manage personal finances and thus public finances.

According to the Public Service Commission, the total debt owed to microlenders by public servants was R13.3 million during the 2006/07 financial year, $25 \%$ of which was attributed to national departments' employees (Public Service Commission, 2008:32). While the Public Service Commission conceded that micro-loans and other credit may sometimes be necessary to alleviate the temporary financial challenges one may face, it was quick to point out that when such is acquired as a result of over-indulgence and as a measure to supplement the monthly salary, the practice raises serious concern. The making of garnisheerelated payment by public servants during the 2006/7 financial year reveals that many public servants are trapped in financial debt and thus default on repayments to their creditors, warranting that court action be taken for them to honour the payments. If this is not unethical conduct on the part of public servants, then what is it?

The financial debt trap of public servants has serious repercussions. Not only does it portray a negative unethical image of the public service, but derails service delivery. The following are some of the consequences: public servants 
engage in irregular remunerative work commonly known as moonlighting. When trying to counter or survive the pressure of high financial debt, the public servants, in particular professionals, perform their duties during the day and engage in other remunerative work at night or vice versa. This places a heavy strain and fatigue on the body, which leads to ill health and low productivity. When public servants have to perform the duties they are employed for in their respective departments, they are half their best, thus professionalism is compromised.

Financially indebted employees become vulnerable to unethical behaviour. If one considers the financial management system's weaknesses and challenges in various departments, one can observe that some of the weaknesses are deliberately unattended to so as to allow space for corrupt tendencies to manifest themselves. This observation is informed by the oversight reports of various portfolio committees, as well as Auditor General's reports of the past fourteen years in various departments and municipalities. The Public Service Commission agrees that being in financial debt could result in an erosion of ethics among public servants, as they could be enticed to commit unethical or corrupt practices.

Recent findings by the Public Service Commission (State of the Public Service Report, 2010:11-12) however, reveal that the situation is improving slightly. Financial disclosure by members of the senior management service has ranged between $73 \%$ and $85 \%$ for the financial years $2005 / 06$ to $2008 / 09$. It is evident that the compliance levels are continuing to improve but the PSC expects $100 \%$ declaration on issues that may have potential conflicts of interest between officials' private interest, for example a debt trap, and their official duties.

Most public servants suffer from stress and addictive behaviour resulting from being trapped in financial debt. This trend negatively affects people's work performance and results in low productivity in the workplace. It leads to a dramatic increase in absenteeism as employees will often miss work to avoid debt collectors. In other cases, employees will resign from their jobs to get access to their pensions, pay their debts and end up being jobless, thus increasing the unemployment statistics. Hard earned skills and experience are lost. Social behaviour for the individual changes, family life suffers and people turn to substance abuse as a means of managing. High levels of financial debt over a long period often lead to anxiety and depression. Debt may lead to depression and the display of such symptoms as insomnia and lack of appetite. Employees feel out of control, useless, hopeless, and in some instances resort to committing suicide. It is indeed true that financial worries lead to psycho-social and other health problems and push people to compromise values and act immorally as 
well as illegally. A situation could arise, for example, where senior public officials borrow money from subordinates and one wonders how discipline, ethical conduct and professionalism in an institution will be maintained in such instances.

One sometimes entertains the notion that some public servants mistakenly believe that they are justified in deviating from generally applicable moral requirements (Price, 2006:60). It is precisely because of the above scenario that the code of conduct of the public service (Chapter M) was introduced.

\section{CODE OF CONDUCT}

There is a code of conduct, which encourages public servants to think and behave ethically. It sets out expectations about acceptable behaviour and benchmarks for ethical practices. It is structured to promote an ethos of dedication and service, evoke a commitment to high standards of professionalism, contribute to more efficient and effective service delivery and eliminate corruption in the public service. The following are the guidelines on the provisions of the code:

- Relationship with the Legislature and the Executive

- Relationship with the public

- Relationship among employees

- Performance of duties

- Personal conduct and private interest.

The code of conduct is available for all to see, but is it adhered to? Is it effective? The same can be asked of the Batho Pele principles, which were also introduced to promote ethical conduct and professionalism in the public service so as to enhance service delivery. The eyes of the public are on the public service for all the wrong reasons. What then are the consequences of an unethical, unprofessional public service?

\section{CONSEQUENCES OF UNETHICAL CONDUCT AND UNPROFESSIONALISM}

According to the United Nations Department of Economic and Social Affairs Division for Public Economics and Public Administration (2000:3), scandals involving public officials have captured world attention with the public not distinguishing between whether those in government are elected or appointed. It is true that any country expects its public service to manifest professionalism 
and ethics. These are critical elements whose absence can lead to, inter alia, the following:

- Minimum development of people and nations

- Disorderliness and anarchy in a society

- Lack of investor confidence, leading to lack of economic growth

- Deterioration of trust by citizens.

- What then are the factors that promote public service professionalism and ethics?

\section{FACTORS THAT MAY ENHANCE PROFESSIONALISM AND ETHICS IN THE PUBLIC SECTOR}

The following may be seen as factors that encourage ethical conduct and professionalism in the public sector:

- Training in basic skills to carry out official duties. Such training may include financial management so that public servants are able to manage own finances.

- The introduction of a career system based on merit appointments. In the January 82010 statement of the ruling party, the point is made that, 'the process of building a new public sector cadre forms part of the major tasks of creating a developmental state'. In the statement, the President further warns those placed in positions of responsibility that do nothing, either through incapacity or unwillingness, that they will be replaced. Shoddy service by councillors is also rebuked in the statement.

- Well-articulated and fair human resource policies on remuneration and conditions of service, training and development programmes should be implemented.

- Recognition of good work through incentives and correction of poor performance, thus nurturing professionalism and pride (United Nations, 2000:6).

- Legalising the Code of Conduct and Batho Pele principles - these will then be enforced against misconduct ranging from unethical to criminal acts.

- Strengthening of human resource capacity to investigate unethical conduct in departments. The PSC reports that in KwaZulu-Natal not 
enough resources were made available to create posts and employ staff for this purpose (2008:19).

- Increasing compliance with the Financial Disclosure Framework - the $70 \%$ (2004/05) and 60\% (2005/06) compliance is, according to the PSC, inadequate (2008:17). Conflicts of interest are rampant in the public service and in municipalities.

- Discontinuing dual employment. The PSC has noted that some public servants also serve as part time councillors and this poses a threat to honesty, especially in bidding.

- Exemplary leadership and political will are needed to instill ethics and professionalism because at times the problems start from the top and permeate the institution. Junior officials take advantage of such situations.

These factors may encourage a public service that adapts to the impacts of globalisation so as to achieve better economic performance through promoting investment and trade (United Nations, 2000:24). Can all public servants be painted with the same brush? The answer is no, because there are good public servants who may be referred to as Batho Pele public servants. Batho Pele means putting people first, in other words treating citizens as customers as in the private sector where the customer is seen as always right. The concept entails the principle of consulting the recipients of services, treating them with courtesy and providing them with information on service delivery-related matters. It further encourages openness on the part of public institutions so that the public may know more about the way government institutions operate, and the setting of standards to constantly measure the extent to which citizens are satisfied with the services or products that they receive, as well as emphasising a need to identify quickly and accurately when services are falling below the promised standards so as to have procedures in place to remedy the situation. These are ethical, professional employees who contribute in ensuring:

- a positive image of the public service

- enhanced service delivery

- citizen confidence in the public service

- investor confidence

- efficient, effective utilisation of resources. 


\section{CONCLUSION}

According to Kernaghan and Dwivedi, (1983:157-158), since the dawn of civilisation, there has been an expected code of right conduct for public officials different from and in many respects superior to private conduct. All practising professionals are expected to follow an agreed pattern of conduct in respect of how they treat other professionals, how they conduct their professional affairs, and how they deal with their clients. They should treat people as significant individuals with feelings, rather than as numbers on a register.

One of the prime responsibilities of a government must be to build an environment of justice, transparency and trust. Around the world, governments and public administrators face crises of confidence. Government itself, in the long term, if not immediately, will fail if it does not carry public confidence. According to Mafunisa (2009:79), the South African public service needs public officials who are competent and loyal to their work. They should use public funds both effectively and efficiently for the benefit of every member of the public. A positive work ethic and attitudes such as loyalty to public service goals and values do not develop automatically. All interested parties should develop ethical norms and the behavioural expectations of public officials.

Public servants are the backbone and heartbeat of the public service, but if this heartbeat is unethical and unprofessional, there will be no blood circulation and the public service will 'die'. There is a need for political will as well as ethical exemplary leadership, as senior public servants remain critical to the effective promotion of ethics in the public service. The Code of Conduct, Batho Pele principles and other prescripts that encourage ethical behaviour and professionalism may need to be considered as legislation so that they are enforceable.

This is so because it is unacceptable that much needed job opportunities are not forthcoming through lack of investor confidence, where disorderliness characterised by protest action becomes the order of the day, and where citizens lose confidence in a government they themselves voted into power.

Furthermore there is a need for the training of public servants, for intolerance of shoddy service to develop, for fair human resource policies, recognition of good work, the strengthening of whistle blowing and protection of whistleblowers. Public institutions should be capacitated to deal with cases of unprofessional and unethical conduct. Conflict of interest needs to be contained, the Financial Disclosure Framework must be complied with, and dual employment must be discouraged. Key to all is, however, exemplary leadership. 


\section{List of References}

- African National Congress Statement, January 8, 2010.

- Andrews, R., Boyne, G. Meier K.J., O'Toole jr, L.J. \& Walker, R.M. Public service performance perspectives on measurement \& management. United Kingdom: Cambridge University Press.

- Bayat, M.S. \& Meyer, I.H..1994. Public Administration. Concept, theory and practice. Halfway House: Southern Book Publishers.

- Code of Conduct, (Chapter M).

- Correia, C., Flynn D., Uliana, D. \& Wormald, M. 2001, Financial management. (4th ed.). Kenwyn: Juta \& Co.

- Constitution of the Republic of South Africa, 1996.

- De Bruijn, H. \& Dickie, W. 2006. Strategies for safeguarding public values in liberalized utility sectors. Public Administration, 84(3).

- Erasmus, P.W. \& Visser, C.B. 1997. Government finance, the first step. Kenwyn: Juta \& Co.

- Gildenhuys, J.S.H. 1991. Ethics and the public sector. Cape Town: Juta and Company.

- Kernaghan, K. \& Dwivedi, O.P. 1983. Ethics in the public service. Comparative perspectives. Brussels: International Institute of Administrative Services..

- Larmour, P. 1990. Public choices in Melanesia, community bureaucracy \& the market in land management. Public Administration \& Development, 10(1).

- Mafunisa, M.J. 2000. Public service ethics. Juta \& Co, Kenwyn

- Pauw, J.C., Woods, G., Van der Linde, G.J.A. \& Visser, C.B. 2002. Managing public money, a system from the South. Cape Town: Heinemann Publishers Pty Ltd.

- Price, T.L. 2006. Understanding ethical failures in leadership. New York: Cambridge University Press..

- Shafritz, J.M. \& Russel, E.W. 2005. Introduction to Public Administration (4th ed.). New York: Pearson.

- State of the Nation Address, 2010, Parliament of the Republic of South Africa. 
- State of the Public Service Report, 2008, Public Service Commission.

- United Nations, 2000, Professionalism and ethics in the public service. Issues \& practices in selected regions. New York: (ST/ESA/PAD/SER.E/5).

- United Nations Development Programme. 2007. Case evidence on ethics and values in civil service reforms.

- White Paper on Transforming Public Service Delivery, 1997.

\section{AUTHOR'S CONTACTS:}

Thozamile Richard Mle

Department of Public Administration

University of Fort Hare

Email: TMle@ufh.ac.za 